\title{
ADRIANA GRIGORESCU
}

AMALIA-ELENA ION

\section{An empirical review of public policies on the sector of SMEs in the European Union}

Prof. Adriana Grigorescu, National University of Political Studies and Public Administration, Department of Public Management,

Romania, ORCID: 0000-0003-4212-6974.

Amalia-Elena Ion, Ph.D. Candidate, Valahia University of Târgoviște, Doctoral School of Management, Romania, ORCID: 0000-0002-5025-4936.

\section{Introduction}

As it is widely discussed whether a common currency area could provide for a better regional stability, and for a far more opportunistic environment for the SMEs of the respective region, the idea of challenging and analysing the public policies across the most productive and powerful economies of the world represents an interesting starting point in the pursuit of understanding how the public policies and governance affect and direct the social and economic contexts of the world, especially those related to the engine of the economy - the SMEs.

Since there is no prior study on the subject, the research is based on a qualitative approach of a content analysis of public policies directed towards the SME sector in the EU. The official documents considered in the study are the SBA for Europe, both 2008 and 2011 versions. After a review of the official documents, the research has identified the coding category groups, the coding categories, the recording units, as to further run a frequency analysis on the latter. After ranking the category groups based on (frequency-related) importance, the paper 
analyses the meaning behind the results, by pointing out the structure and content of the SBA for Europe.

The focus of this paper shall therefore be the identification of the general strategy of public policies in the field of SMEs within the European Union.

\section{Literature review - EU public policy}

The principal scope of the paper is the evaluation of the SME legislative measures within the European Union. The following part of the article is meant to showcase the main historical milestones achieved by the EU legislature surrounding the given topic. There is no previous research in economic law regarding the subject of EU-28 SME public policy, in general, and regarding the Small Business Act for Europe, in particular.

After the Second World War, Europe was trying to reconfigure the relationships between its neighboring states, and, in 1957, the European Economic Community was created under the Treaty of Rome, a treaty signed by Belgium, the Netherlands, France, Italy, Luxembourg and West Germany. During the 1960s, the common market has experienced a growth period, aided by the fact that the EU countries have started trading without charging custom duties, and they joint-controlled the agricultural production.

In 1986, the Single European Act is signed. It represented the first step into creating a single market across Europe. During the 1990s the rest of the communist regimes across central and Eastern Europe have collapsed. During 1990-1999, Europe becomes the land of the free movement of goods, services, people and money. By 1995, the Schengen agreement is also instituted, and, for the first time in modern Europe's history, people can move across borders without having their documents checked at the borders. With this new internationalisation of the European market, students have the privilege of studying abroad with the help and support of the European Union. Communication is also improved by the spread of the Internet and mobile phones.

During the 2000s, the global economic crisis strikes hard in Europe, and the European Union has to start showing support to its member states. With the ratification and the entering into force of the Treaty of Lisbon, the constitutional basis of the European Union is upgraded, with the scope of bettering the efficiency of the community and its legitimacy as a democratic Union. The last decade in the history of the European Union, between 2010-2019, has presented many challenges, from the climate change issues, to the military activity of Russia in Ukraine and Crimea. Most member states have faced difficulties under 
the form of reminiscent problems triggered by the economic crisis of 2009, as well as several terrorist attacks, and the most recent refugee migration towards Europe.

The EU has formed around critical economic periods of time, and the founding members of the council have decided to create programmes that help the member states and the Union to smoothly go past the less fortunate economic moments. As a result, numerous public policies, directives and legislations have guarded the stability and safety of the European Union, among which the Single European Act of 1986. With the latter a rebranded single European market was completed by 1992. In accord, the legislation and policies have been created and instituted first by introducing the qualified majority voting (QMV) that cooperated with the European Parliament in legislative matters. Moreover, the SEA has also innovated through the creation of the Court of First Instance to assist in legislative and juridical cases, mostly related to competition and unfair trade. The enactment of the SEA represented the step towards a unified Europe, where the supranational Union of the member states rendered the internal single market towards success and profitability.

With the Treaty of Amsterdam in 1997 not bringing the expected results for the European further integration, Germany and France have loudly and constantly discussed and presented ways of creating the unified, democratic and prosperous European continent. The introduction (in 2002) of the Euro as a currency in twelve member states has amplified the importance of the European integration. The process of European integration raised the attention towards the role of the individual member states in the decision-making of the EU policies.

This next step of the EU integration, that started in the 2000s, commenced with the liberalisation of the trade of services, given that services created (and still account for) 9 out of 10 jobs in the EU. In 2009, all EU member states have implemented the Services Directive, introduced by the EU Commission in 2006, with the sole purpose of finding the non-democratic practices in the field, starting by regulating the services market in terms of discrimination, administrative procedures, or licensing rules - especially due to the fact that SMEs did not have access to learning licensing as a result of the high costs. In the last case, the European Commission has formally introduced the Point of Single Contact, which regulates the legislation and acts as a supervisor for access to the information through e-government portals, or other specialised websites. Therefore, any company based in any EU member state had the right to sell its services in any other member state without being hindered by any national legislation. 
Nonetheless, this did not mean that the process has been smooth and easy. On the contrary, there have been some daunting differences across member states in terms of registration, licensing and insurance requirements, qualifications recognition, and market directives. The economic impact of a common market had to be regulated, and the competition had to be transparent and fair, as for the less developed areas of the common market (e.g. markets from developing countries) to make it easier to take part of the trade on the common market without constantly being assaulted by the corresponding economic agents from the developed countries.

The EU has tried different approaches in order to work out the market liberalisation. Nonetheless, it is still far from achieving the idealised purpose of a free movement market, in part due to the member states protecting their domestic market, and in part due to the high risk many goods and services carry. There is also a discrepancy in terms of points of view. That is, if a member state finds GMO foods unacceptable for human consumption, some other member states will not have the same opinion on the matter. Moreover, many goods and services are regulated in domestic markets, which means that those particular products and services will not liberally flow through the EU market. The non-regulated goods and services are the ones that will be traded across the EU market. One example of regulated industries is the pharmaceutical market. The result of that brings up cases like the following: a certain medical treatment recommended by a physician in Romania will not be available on the domestic market due to the regulations of the domestic market that forbid certain chemicals that are found in that particular treatment. The same medication is sold on the German market, only with a medical prescription.

The EU Treaty on the functioning of the Union and the single market states in Chapter 3, Article 114 that the internal legislation of member states must follow a certain structure to respect the good functioning of the common market. One of the ways of insuring that the common market works for all member states was by instituting common features (that must be found in products and services throughout the EU market), and detailed and specific regulation (that would help the market in achieving approximation). The latter refers to, for example, the quantity admitted of preservatives that must be found in foods in order to prolong their lifespan. The finally instituted measure for keeping track of all the goods and services on the common market was realised through the adoption of the EU standards controlled by the EU legislation and the European Standard Organisations that will specify the technicalities. 
In 2009, the European Commission has laid out an Action Plan for European Standardisation, and, in 2017, the Annual Union Work Programme for Standardisation. The last two bodies of strandardisation stipulate the essential requirements for products and services that are to be traded on the European common market, while the ESOs, among which the most important is the European Committee for Standardisation or the CEN, will look over the specifications in more than 18 industrial sectors. There are also bodies of strandardisation that look specifically into a certain sector (e.g. CENELEC, ETSI), but, nonetheless, all the essential requirements are to be translated into national laws, as ESO standards are facultative. In 2012, the European Commission has made public the fact that half of the goods traded within the European Union's common market are subject to the approximation directives, while the other half is not.

While "US corporations profited from economies of scale in a large homogenous home market, supported by a common currency, one language and a rather business-friendly antitrust regime, European corporations were generally smaller in size, while the European marketplace continued to be highly fragmented along national lines" (Zahariadis, N., Buonanno, L. 2017, p. 78). As a result, the Commission has permitted cross-border cooperation agreements, and the creation of European champions. The issue of employment has also been a central concern of the Commission. All in all, the European Commission has focused on creating the perfect playground for large enterprises to access and supply the common market, in order to deliver to the European consumer goods and services at affording prices.

In order to ensure fair trade and fair competition, the European Commission adopted a series of measures for gradually diminishing the protectionist strategies, and forced the national governments to prosecute any act that might hinder the competition rules. The Commission has the authority of imposing a fine up to $10 \%$ of the company's turnover, in case it is demonstrated that the above-mentioned company is using unfair competition strategies. This way of thinking has been furthered towards other industries, not only across the business world. The public policies in the EU have had from the beginning this particular focus on competition rules, justified by the notion of the market justice and the fairness in relation to the consumer or the European citizen. The consumer welfare and the efficiency of the system, backed by low pricing resulted from econometric price modelling, has spread the neoliberalism at the end of the $19^{\text {th }}$ century and the beginning of the $21^{\text {st }}$ century. 
In 2004, the merger regulation adopted in 1989 has been revised in accord to neoliberalism practices, with the purpose of facilitating the economic concentration and to avoid the involvement of the national authorities. One more area where the EU has paid attention, and has tried to make the European businesses competitive internationally was the cooperation with emerging countries, China, India or Brazil, and the focus on building competitive advantages that are inspired from those of the emerging economies such as cheap labour force. The latter represents the effect of intensified inter-company competition.

The European Union is now facing a new world order. With internal shifts triggered by the Brexit, the rise of populist and nationalist parties, and all the changes that come from outside (failed trade agreements, increased taxation on exports, political 'dystrophies', increased global gap between rich and poor, laboratory developed diseases, increased world population, problems in the transportation industry etc.), the EU must take into consideration new ways of instituting the pace in the region, and that will represent a lesson for all member states, and a mean of consolidating the Union through strong public policies.

\section{Methodology - Content Analysis}

The current study follows a content analysis of a legislative document of the European Union, the Small Business Act for Europe, concerning the SME sector of the economy. The reason for choosing this type of research approach resides in the need of collecting and organizing the unstructured data into a standardised format that would further allow the analyst to make inferences about the meaning and the characteristics of the written material.

The results of the documentations' observation were analyzed in order to organize the information gathered in a standardized format, allowing for inferences about the meaning, and content of the documents. Due to the fact that the documents contain understandable information, a simple content analysis format was used, where the information was summarized, and the frequency of the units of analysis was calculated for each category of written material.

Finally, without the necessity of sampling from the universe of information gathered, the comparison of statements from the two sources was performed, and with the data from the content analysis, a conclusion has been drawn.

The context units utilized were paragraphs under each official document taken further into the study. They divide the content of the documents in 
logical sequences of information. The context units have the same importance. Within each context unit, recording units were identified under the form of groups of words or sentences. The Appendix contains the detailed tables with the extraction of context units from the official documents, and the recording units from each context unit. Moreover, the following categories have been used to measure the frequency of the recording units: access to financial resources for SMEs, regulatory and legal frameworks for a better environment for SMEs, public assistance on information and knowledge about markets for SMEs. Frequency is used to measure the number of times a statement occurs in a text, and for this particular study, frequency is a valid indication of importance. The context units were clustered in different categories, depending on the meaning attributed to the recording units extracted from the context units.

The content analysis was performed as depicted in the frequency analysis in table 1 . The recording units were catalogued in different categories, depending on the context units' meaning. The frequency of the recording units was further calculated. For each category an analysis based on the ratio of absolute and relative frequency was calculated, and then a classification was made. The category with the highest number of recording units was the most debated in the analysed documents.

\section{Discussion General strategy on public policies affecting SMEs in the EU}

The case study is based on the content analysis of the following two official government documents - the Small Business Act for Europe (2008), and the Small Business Act for Europe Review (2011). After running the content analysis, the European perspective on the SMEs public policies has been determined. It is evident that the European model of the Small Business Act has been 'inspired' from the American counterpart, although the interpretations have been completely different. The European Small Business Act was, first of all, written in a less abstract manner, pointing out, rather from a business perspective, all the elements that should and could be tackled by the administration regarding the ever important SME European sector.

Known also as the 'engine' of the European economy, the SME industry was put under the spotlight, pointing out exactly those elements that appeared to blink yellow or red in terms of legislative basis. The European Small Business Act of 2008 is constructed around 10 principles that have all been inserted into the analysis of the given paper (see Appendix). 
Table 1. Frequency analysis of SBA for Europe (2008) and SBA for Europe Review (2011)

\begin{tabular}{|c|c|c|c|c|}
\hline Category group & Categories & Recording units & $\begin{array}{c}\text { Frequency } \\
\text { of recording } \\
\text { units }\end{array}$ & Total \\
\hline \multirow[t]{5}{*}{$\begin{array}{l}\text { A. Access to } \\
\text { resources for SMEs }\end{array}$} & $\begin{array}{l}\text { Access to information, } \\
\text { services and raw resources; } \\
\text { development of points of } \\
\text { single contact }\end{array}$ & $\begin{array}{l}\text { J19.1, J19.2, J26.2, } \\
\text { J26.3, J27.1 }\end{array}$ & 5 & \multirow[t]{5}{*}{19} \\
\hline & Access to financial resources & I18.1, J12.1 & 2 & \\
\hline & Access to human resources & I2.1, I4.1, I10.1 & 3 & \\
\hline & Innovation and productivity & $\begin{array}{c}\text { I1.1, I3.1, I20.1, J9.1, } \\
\text { J30.1 }\end{array}$ & 5 & \\
\hline & $\begin{array}{c}\text { Business development and } \\
\text { diversification }\end{array}$ & $\mathrm{I} 20.2, \mathrm{I} 21.1, \mathrm{I} 22.1, \mathrm{~J} 2.3$ & 4 & \\
\hline \multirow{7}{*}{$\begin{array}{l}\text { B. Regulatory and } \\
\text { legal frameworks } \\
\text { for SMEs }\end{array}$} & Social public policy & $\mathrm{J} 31.1$ & 1 & \multirow[t]{7}{*}{36} \\
\hline & $\begin{array}{l}\text { Monetary and fiscal public } \\
\text { policy }\end{array}$ & $\begin{array}{l}\text { J2.1, J3.1, J4.1, J14.1, } \\
\text { J20.1, J20.2, J21.1 }\end{array}$ & 7 & \\
\hline & Entrepreneurship public policy & I7.1, I11.1, I13.1 & 3 & \\
\hline & $\begin{array}{l}\text { General SME public policy } \\
\text { (e.g. needs of SMEs at the } \\
\text { core of EU policy, reduction } \\
\text { of administrative burdens } \\
\text { on SMEs, second chance } \\
\text { programmes in case of } \\
\text { bankruptcy etc.) }\end{array}$ & $\begin{array}{l}\text { I5.1, I6.1, I8.1, I9.1, } \\
\text { I14.1, I15.1, I16.1, } \\
\text { I17.1, I23.1, I23.2, } \\
\text { J1.1, J2.2, J16.1, J17.1, } \\
\text { J17.2, J18.1, J28.1 }\end{array}$ & 17 & \\
\hline & $\begin{array}{c}\text { Federal partnership (e.g. } \\
\text { Smart specialisation strategies, } \\
\text { monitoring and coordinating } \\
\text { mechanisms etc.) }\end{array}$ & $\begin{array}{l}\text { I12.1, J10.1, J11.1, } \\
\text { J26.1, J27.2 }\end{array}$ & 5 & \\
\hline & Gender/Minority public policy & J8.1 & 1 & \\
\hline & $\begin{array}{l}\text { Legal measures for protecting } \\
\text { and benefiting SMEs (e.g. } \\
\text { protect businesses against } \\
\text { unfair contractual terms) }\end{array}$ & $\mathrm{J} 22.1, \mathrm{~J} 23.1$ & 2 & \\
\hline
\end{tabular}




\begin{tabular}{|c|c|c|c|c|}
\hline \multirow{3}{*}{$\begin{array}{l}\text { C. Public assistance } \\
\text { on information and } \\
\text { knowledge about } \\
\text { markets for SMEs }\end{array}$} & Start-ups & I17.2, J15.1 & 2 & \multirow[t]{3}{*}{11} \\
\hline & Business information & I19.1, J5.1, J29.1 & 3 & \\
\hline & $\begin{array}{l}\text { SME internationalisation and } \\
\text { expansion }\end{array}$ & $\begin{array}{l}\text { I22.2, J6.1, J7.1, J13.1, } \\
\text { J24.1, J25.1 }\end{array}$ & 6 & \\
\hline \multicolumn{4}{|l|}{ Total } & 66 \\
\hline
\end{tabular}

The importance of the group categories was calculated, and the following results have been achieved - Category A represents $28.78 \%$ of total; Category B represents $54.54 \%$ of total; Category C represents $16.66 \%$ of total. The results showcase the importance given to the development of regulatory and legal frameworks for SMEs in areas that pertain to social, fiscal and monetary, entrepreneurship, gender public policy, as well as the collaboration between the EU central administration and that of the Member States, and all the legal measures designed to protect and be of benefit to SMEs, such as contractual clauses, business networks, or international partnerships. Generally, the SBA for Europe comprises of all the information that was identified through research and intensive SME industry studies as challenging for the area.

Therefore, the structure of the Small Business Act for Europe resembles that of a market research with the ten principles at the core of the act. Second in importance within the SBA for Europe has been the discussion regarding the access to resources of SMEs. The latter comprised of access to information, services and raw resources, development of points of single contact, access to financial resources, to human resources, as well as innovation, productivity, business development and diversification. The public assistance on information and knowledge about markets for SMEs is still a chapter that needs further improvements. This area focuses on all the market knowledge that could prove useful to any SME that decides to enter a new market, to export, or to internationalise. The Member States should tackle this matter by providing with more centres for information on SME expansion and internationalisation, with multilingual bureaus of business development and planning.

As observed above, the European SBA is still in incipient form, with only 20 pages of recommendations and reviews, from a legislative point of view, and, according to the 2011 Review, there are still key elements that have either not been discussed at all or are only partly under consideration. Nevertheless, there must be underlined that the European approach to the SME regulation is very

世

ADRIANA GRIGORESCU

AMALIA-ELENA ION 
much business-like, having the possibility of concluding that the SBA for Europe is very much contemporary and globally oriented.

In the end, it must be acknowledged that the present research is only preliminary, and to better understand the mechanisms behind the European policy, further the studies on the subject are necessary. Nevertheless, the study has managed to point out that, starting from the premise that public policy in the SME industry represents one of the most important aspects of our new economic direction, the new world order calls for attention to the last detail, SMEs are the sector of the economy that moves the wheels from the lowest level to the highest, and that, in a globalised world, the economic integration represents the first strong evidence of a new era - the world went from getting small to being tiny.

\section{Conclusions}

The content analysis has proved that the European SBA has a persistent business approach to the whole problems raised by the now compact European SME industry.

The advantages of the SBA for Europe are definitely represented by the to the point' form of the act, and by it being rooted in reality. The 10 principles of the act have been drawn only after extensive market research in the field of SMEs, taking into consideration even opinions of the questioned business owners and entrepreneurs. Actually, the first principle of the EU SBA is that of promoting entrepreneurship, especially from the beginning of the children's education.

There are a number of European Member States that have developed entrepreneurship programmes to either facilitate the transfer of businesses (Austria), to support and mentor start-ups run by women (Sweden), or to develop the entrepreneurial skills of young people and to support start-ups (Romania). Another element found at the core of the SBA for Europe is represented by the idea of providing the perfect hub for start-ups. Moreover, there was clear identification of references to the case of SMEs that faced first time bankruptcy and discussion about possible procedures that could bring succour the respective SMEs. The European SBA underlined this matter under the second principle of the Act, with good examples of Member States (Belgium, Finland, Ireland, Spain and the UK) already complying with the recommendations of the Commission. The next principles of the EU SBA revolve around the idea of reducing the administrative burden on the SMEs, of making the administration more responsive to the needs of the SMEs by promoting e-government and points of 
single contact solutions, by adapting the public procurement procedures, make better use of Community Aid and start-up incentives, by improving the Single Market policy, by encouraging innovation and R\&D, by turning environmental challenges into opportunities, by supporting SMEs to grow and expand outside of the Single Market, by facilitating the access to finance of SMEs.

All in all, even if the SBA for Europe has taken the name from the American counterpart, its greatest achievement is probably the fact that it is not really a superficial Act, but actually a step forward in understanding the SME sector, in working on public policies that tackle real-world problems, in bringing all sorts of people together and creating a universal cooperative system of entrepreneurs, small business owners and innovators.

\section{Summary}

An empirical review of public policies on the sector of SMEs in the European Union

The paper aims to provide with a close picture of the SME public policies in one of the most prominent capitalist economies of the world, that of the European Union. In order to do this, a qualitative analysis has been undergone, on the basis of the following indicators: access to financial resources for SMEs, regulatory and legal frameworks for SMEs, and public assistance on information and knowledge about markets. Since there is no prior research on the subject, the implications of this paper have impact on the theory, practice and policy making. The results of the content analysis suggest that there is a contemporary structure to the European SBA, with a focus on a persistent business approach, based on the results of scientific research and market studies involving the problems raised by the now compact European SME industry. In the end, it must be acknowledged that the present research is only preliminary, and to better understand the mechanisms behind the European policy, further studies on the subject are necessary. Nevertheless, the paper has managed to point out that public policy in the SME industry represents one of the most important aspects of the EU-28 new economic direction.

Key words: public policy, qualitative analysis, content analysis, SME public policy.

JEL: $\quad$ H19, M20, Z18 


\section{References:}

1. Annual Report 2013 [Web log post]. Retrieved June 2, 2019, from https:// www.ecb.europa.eu/pub/pdf/annrep/ar2013en.pdf.

2. Communication from the Commission to the Council, The European Parliament, The European Economic and Social Committee and the Committee of the Regions "Think Small First" A "Small Business Act" for Europe, Brussels, 25.6.2008 COM (2008) 394 final [Web log post]. Retrieved June 2, 2019, https:/ / eur-lex.europa.eu/legal-content/EN/TXT/PDF/?u ri $=$ CELEX:52008DC0394\&from $=$ EN.

3. Communication from the Commission to the European Parliament, the Council, Economic and Social Committee and the Committee of the Regions Review of the "Small Business Act" for Europe, Brussels, 23.2.2011 COM (2011) 78 final [Web log post]. Retrieved June 2, 2019, https:/ / eurlex.europa.eu/legal-content/EN/TXT/PDF/?uri=CELEX:52011DC0078 \&from $=\mathrm{EN}$.

4. Consolidated version of the Treaty on the Functioning of the European Union [Web log post]. Retrieved June 2, 2019, https:/ / eur-lex.europa.eu/ legal-content/EN/TXT/PDF/?uri=CELEX:12012E/TXT\&from=EN.

5. Consolidated version of the Treaty on the Functioning of the European Union, Title VIII: Economic and Monetary Policy [Web log post]. Retrieved June 2, 2019, from https://en.wikisource.org/wiki/Consolidated_ version_of_the_Treaty_on_the_Functioning_of_the_European_Union/ Title_VIII:_Economic_and_Monetary_Policy\#Article_130.

6. Delors, J. (1989). Report on economic and monetary union in the European Community. Presented April 17, 1989 (commonly called the Delors Plan or Report) By Committee for the Study of Economic and Monetary Union. [EU Commission - Working Document].

7. Directive 2014/49/EU on deposit guarantee schemes [Web log post]. Retrieved June 2, 2019, from https://eur-lex.europa.eu/legal-content/ RO/TXT/PDF/?uri=CELEX:32014L0049\&from=EL

8. El-Agraa, A.M. (2007). The European Union: Economics and Politics, New York: Cambridge University Press.

9. European Union History [Web log post]. Retrieved June 2, 2019, from https://europa.eu/european-union/about-eu/history_en.

10. Fischer, F., Miller, G.J., Sidney, M.S. (2007). Handbook of Public Policy Analysis. Theory, Politics and Methods. London: Taylor \& Francis Group.

11. GAO, (1989). Content Analysis: A Methodology for Structuring and Analyzing Written Material, Transfer paper 10.1.3.

12. Guideline of the European Central Bank of 20 March 2013 on additional temporary measures relating to Eurosystem refinancing operations and eligibility of collateral and amending Guideline ECB/2007/9 [Web log post]. Retrieved June 2, 2019, from https://www.ecb.europa.eu/ecb/ legal/pdf/1_09520130405en00230030.pdf.

13. Sapru, R.K. (2004). Public Policy, New Delhi: Sterling Publishers Pvt. Ltd.

14. SMALL BUSINESS ACT (Public Law 85-536, as amended) of the United States of America, including PL 114-125, enacted 2/24/16 [Web log 
post]. Retrieved June 2, 2019, https://www.sba.gov/sites/default/ files/2019-03/Small_Business_Act.pdf.

15. Treaty of Rome (1957) [Web log post]. Retrieved June 2, 2019, from https:// ec.europa.eu/romania/sites/romania/files/tratatul_de_la_roma.pdf.

16. Zahariadis, N., Buonanno, L. (2017). The Routledge Handbook of European Public Policy, Abigdon: Routeledge.

\section{Appendix}

Table 2. Content Analysis of the Small Business Act for Europe (2008)

\begin{tabular}{|c|c|c|c|}
\hline \multicolumn{4}{|c|}{$\begin{array}{c}\text { COMMUNICATION FROM THE COMMISSION TO THE COUNCIL, THE EUROPEAN } \\
\text { PARLIAMENT, THE EUROPEAN ECONOMIC AND SOCIAL COMMITTEE } \\
\text { AND THE COMMITTEE OF THE REGIONS } \\
\text { "Think Small First" A “Small Business Act” for Europe (2008) }\end{array}$} \\
\hline Code & Context units & Code & Recording units \\
\hline I1 & "Transition towards a knowledge-based economy" & I1.1 & Knowledge-based economy \\
\hline $\mathrm{I} 2$ & "A higher level of social cohesion" & $\mathrm{I} 2.1$ & Social cohesion \\
\hline I3 & $\begin{array}{l}\text { "Our capacity to build on the growth and innovation } \\
\text { potential of small and medium-sized enterprises } \\
\text { (SMEs) will therefore be decisive for the future } \\
\text { prosperity of the EU" }\end{array}$ & I3.1 & $\begin{array}{l}\text { Growth and innovation } \\
\text { potential of SMEs }\end{array}$ \\
\hline $\mathrm{I} 4$ & $\begin{array}{l}\text { "The role of SMEs in our society has become even } \\
\text { more important as providers of employment } \\
\text { opportunities and key players for the wellbeing of } \\
\text { local and regional communities" }\end{array}$ & I4.1 & $\begin{array}{l}\text { SMEs as providers of } \\
\text { employment opportunities } \\
\text { and key players for the } \\
\text { wellbeing of communities }\end{array}$ \\
\hline I5 & $\begin{array}{l}\text { "The EU has thus firmly placed the needs of SMEs } \\
\text { at the heart of the Lisbon Growth and Jobs Strategy, } \\
\text { notably since } 2005 \text { with the use of the partnership } \\
\text { approach, which has achieved tangible results" }\end{array}$ & I5.1 & $\begin{array}{l}\text { EU placed needs of SMEs at } \\
\text { the heart of Lisbon Growth } \\
\text { and Jobs Strategy }\end{array}$ \\
\hline I6 & $\begin{array}{l}\text { "To cement the needs of SMEs in the forefront of the } \\
\text { EU's policy" }\end{array}$ & I6.1 & $\begin{array}{l}\text { Needs of SMEs in the } \\
\text { forefront of EU policy }\end{array}$ \\
\hline I7 & $\begin{array}{l}\text { "Both the Member States and the EU have made } \\
\text { progress in creating an SME-friendlier business } \\
\text { environment" }\end{array}$ & I7.1 & $\begin{array}{l}\text { Progress in creating } \\
\text { SME friendlier business } \\
\text { environment }\end{array}$ \\
\hline
\end{tabular}


I8 "The Commission has made real efforts to cut red tape for SMEs and has significantly increased the SME focus in major EU support programmes for 2007-2013 (...)taking inspiration from best practice exchanged in the context of the European Charter for Small Enterprises endorsed in Feira in 2000 and by implementing the 2006 Spring European Council conclusions, e.g. by introducing one-stop shops for company registration and reducing the time and costs required to start a business"

I9

"The EU's strategy for better regulation is crucial for SMEs, which will greatly benefit from the modernisation and simplification of existing EU legislation and from the ambitious programme to reduce administrative burdens arising from EU legislation by $25 \%$ by $2012 "$

I10 “In general, EU SMEs still have lower productivity and grow more slowly than their counterparts in the United States. In the US, surviving firms on average increase their employment by $60 \%$ by their seventh year, while employment gains among surviving firms in Europe are in the order of $10 \%$ to $20 \%$. SMEs still face market failures undermining the conditions in which they operate and compete with other players in areas like finance (especially venture capital), research, innovation and the environment. For example, about $21 \%$ of SMEs indicate that accessing finance is a problem, and in many Member States the percentage is much higher for micro-enterprises. Also, fewer European SMEs innovate successfully when compared to large businesses. The situation is worsened by structural difficulties such as the lack of management and technical skills, and remaining rigidities in labour markets at national level"

I11 “This is why the "Small Business Act" aims to improve the overall policy approach to entrepreneurship, to irreversibly anchor the "Think Small First" principle in policy- making from regulation to public service, and to promote SMEs' growth by helping them tackle the remaining problems which hamper their development" partnership between the EU and Member States that respects the principles of subsidiarity and proportionality"

\begin{tabular}{|l|l}
\hline I8.1 & $\begin{array}{l}\text { The Commission has } \\
\text { increased the SME focus } \\
\text { in major EU support } \\
\text { programmes for 2007-2013 }\end{array}$ \\
\hline I9.1 & $\begin{array}{l}\text { Programme to reduce } \\
\text { administrative burdens from } \\
\text { EU legislation }\end{array}$ \\
\hline I10.1 & $\begin{array}{l}\text { Structural difficulties and } \\
\text { rigidities in labour markets at } \\
\text { national level }\end{array}$
\end{tabular}

I11.1 Improve the overall policy approach to entrepreneurship

I12.1 Genuine political partnership between the EU and member states 


\begin{tabular}{|c|c|c|c|}
\hline I13 & $\begin{array}{l}\text { "Create an environment in which entrepreneurs and } \\
\text { family businesses can thrive and entrepreneurship is } \\
\text { rewarded. They need to care for future entrepreneurs } \\
\text { better, in particular by fostering entrepreneurial } \\
\text { interest and talent, particularly among young people } \\
\text { and women, and by simplifying the conditions for } \\
\text { business transfers" }\end{array}$ & I13.1 & $\begin{array}{l}\text { Fostering entrepreneurial } \\
\text { interest and talent, } \\
\text { particularly among young } \\
\text { people and women }\end{array}$ \\
\hline I14 & $\begin{array}{l}\text { "The Member States should ensure that honest } \\
\text { entrepreneurs who have faced bankruptcy quickly } \\
\text { get a second chance" }\end{array}$ & I14.1 & Second chance \\
\hline $\mathrm{I} 15$ & $\begin{array}{l}\text { "The EU and Member States should design rules } \\
\text { according to the "Think Small First" principle by } \\
\text { taking into account SMEs' characteristics when } \\
\text { designing legislation, and simplify the existing } \\
\text { regulatory environment" }\end{array}$ & I15.1 & $\begin{array}{l}\text { Simplify the existing } \\
\text { regulatory environment }\end{array}$ \\
\hline I16 & $\begin{array}{l}\text { "The EU and Member States should make public } \\
\text { administrations responsive to SME needs, making life } \\
\text { as simple as possible for SMEs, notably by promoting } \\
\text { e- government and one-stop-shop solutions" }\end{array}$ & I16.1 & $\begin{array}{l}\text { Public administrations } \\
\text { responsive to SME needs }\end{array}$ \\
\hline \multirow[t]{2}{*}{ I17 } & \multirow{2}{*}{$\begin{array}{l}\text { "The EU and the Member States should adapt public } \\
\text { policy tools to SME needs. They should make use } \\
\text { of the Code of Best Practice providing guidance to } \\
\text { contracting authorities on how they may apply the } \\
\text { EC public procurement framework in a way that } \\
\text { facilitates SMEs' participation in public procurement } \\
\text { procedures. To address the market failures that SMEs } \\
\text { face throughout their lifecycle they should make } \\
\text { better use of the possibilities offered by Community } \\
\text { State Aid rules to support start-ups and provide } \\
\text { incentives for SMEs" }\end{array}$} & I17.1 & $\begin{array}{l}\text { Guidance to contracting } \\
\text { authorities / facilitate SMEs' } \\
\text { participation in public } \\
\text { procurement procedures }\end{array}$ \\
\hline & & I17.2 & $\begin{array}{l}\text { Support start-ups and } \\
\text { provide incentives to SMEs }\end{array}$ \\
\hline I18 & $\begin{array}{l}\text { "The EU and Member States should facilitate SMEs' } \\
\text { access to finance, in particular to risk capital, micro- } \\
\text { credit and mezzanine finance and develop a legal } \\
\text { and business environment supportive to timely } \\
\text { payment in commercial transactions" }\end{array}$ & I18.1 & $\begin{array}{l}\text { Facilitate SMEs' access to } \\
\text { finance }\end{array}$ \\
\hline I19 & $\begin{array}{l}\text { "The EU and Member States should encourage } \\
\text { SMEs to benefit more from the opportunities } \\
\text { offered by the Single Market, in particular through } \\
\text { improving the governance of and information on } \\
\text { Single Market policy, enabling SMEs' interests to be } \\
\text { better represented in the development of standards } \\
\text { and facilitating SMEs' access to patents and trade } \\
\text { marks" }\end{array}$ & I19.1 & $\begin{array}{l}\text { Improving the governance } \\
\text { of and information on Single } \\
\text { Market policy }\end{array}$ \\
\hline
\end{tabular}




\begin{tabular}{|c|c|c|c|}
\hline \multirow[t]{2}{*}{ I20 } & \multirow{2}{*}{$\begin{array}{l}\text { "The EU and Member States should promote } \\
\text { the upgrading of skills in SMEs and all forms of } \\
\text { innovation. They should encourage investment in } \\
\text { research by SMEs and their participation in R\&D } \\
\text { support programmes, transnational research, } \\
\text { clustering and active intellectual property } \\
\text { management by SMEs" }\end{array}$} & I 20.1 & $\begin{array}{l}\text { Promote the upgrading of } \\
\text { skills in SMEs and all forms } \\
\text { of innovation }\end{array}$ \\
\hline & & I20.2 & $\begin{array}{l}\text { Encourage investment in } \\
\text { research by SMEs }\end{array}$ \\
\hline I21 & $\begin{array}{l}\text { "The EU and Member States should enable SMEs to } \\
\text { turn environmental challenges into opportunities. } \\
\text { They should provide more information, expertise } \\
\text { and financial incentives for full exploitation of the } \\
\text { opportunities for new "green" markets and increased } \\
\text { energy efficiency, partly through the implementation } \\
\text { of environmental management systems in SMEs" }\end{array}$ & I21.1 & $\begin{array}{l}\text { Implementation of } \\
\text { environmental management } \\
\text { systems in SMEs }\end{array}$ \\
\hline \multirow[t]{2}{*}{ I22 } & \multirow{2}{*}{$\begin{array}{l}\text { "The EU and Member States should support and } \\
\text { encourage SMEs to benefit from the growth of } \\
\text { markets outside the EU, in particular through } \\
\text { market-specific support and business training } \\
\text { activities" }\end{array}$} & I22.1 & $\begin{array}{l}\text { Encourage SMEs to benefit } \\
\text { from the growth of markets } \\
\text { outside the EU }\end{array}$ \\
\hline & & I22.2 & $\begin{array}{l}\text { Market-specific support and } \\
\text { business training }\end{array}$ \\
\hline \multirow[t]{2}{*}{ I23 } & \multirow{2}{*}{$\begin{array}{l}\text { "The SBA should be fully embedded in the } \\
\text { Growth and Jobs Strategy to ensure its efficient } \\
\text { implementation and to allow for a regular update on } \\
\text { its deliverables. Member States are therefore invited } \\
\text { to take advantage of the update of the Lisbon cycle } \\
\text { planned for the end of } 2008 \text { to take account of the } \\
\text { SBA in their National Reform Programmes and in } \\
\text { their annual implementation reports" }\end{array}$} & I23.1 & $\begin{array}{l}\text { SBA embedded in the } \\
\text { Growth and Jobs Strategy }\end{array}$ \\
\hline & & I 23.2 & $\begin{array}{l}\text { Account SBA in National } \\
\text { Reform Programmes and } \\
\text { annual implementation } \\
\text { reports }\end{array}$ \\
\hline
\end{tabular}

Table 3. Content Analysis of the Small Business Act for Europe Review (2011)

COMMUNICATION FROM THE COMMISSION TO THE EUROPEAN PARLIAMENT, THE COUNCIL, ECONOMIC AND SOCIAL COMMITTEE AND THE COMMITTEE OF THE REGIONS

Review of the „Small Business Act” for Europe (2011)

\begin{tabular}{l|l|l|l}
\hline Code & Context units & Code & \multicolumn{1}{|c}{ Recording units } \\
\hline J1 & $\begin{array}{l}\text { "The SBA must contribute to achieving the ambitious } \\
\text { objectives of the Commission's new reform agenda, } \\
\text { the Europe 2020 strategy, in which several SME- } \\
\text { relevant actions have already been set out in the key } \\
\text { flagship initiatives" }\end{array}$ & $\begin{array}{l}\text { Europe 2020 strategy/ } \\
\text { reform }\end{array}$ & \\
\hline
\end{tabular}




\begin{tabular}{|c|c|c|c|}
\hline \multirow[t]{3}{*}{$\mathrm{J} 2$} & \multirow{3}{*}{$\begin{array}{l}\text { "The delivery of the Europe } 2020 \text { strategy requires, } \\
\text { in addition to fiscal consolidation, pro-active policies } \\
\text { to drive growth in the EU, including measures to } \\
\text { improve the environment for industry and business, } \\
\text { in particular SMEs" }\end{array}$} & $\mathrm{J} 2.1$ & Fiscal consolidation \\
\hline & & $\mathrm{J} 2.2$ & $\begin{array}{l}\text { Pro-active policies to drive } \\
\text { growth }\end{array}$ \\
\hline & & $\mathrm{J} 2.3$ & $\begin{array}{l}\text { Improve the environment } \\
\text { for industry and business }\end{array}$ \\
\hline $\mathrm{J} 3$ & $\begin{array}{l}\text { "Businesses with a turnover of less than } € 2 \text { million } \\
\text { may benefit from an optional cash accounting scheme } \\
\text { which makes it possible for them to delay accounting } \\
\text { for VAT until they receive payment from their } \\
\text { customers" }\end{array}$ & $\mathrm{J} 3.1$ & $\begin{array}{l}\text { Optional cash accounting } \\
\text { scheme }\end{array}$ \\
\hline $\mathrm{J} 4$ & $\begin{array}{l}\text { "To improve SMEs' access to finance, financial } \\
\text { instruments within the Competitiveness and } \\
\text { Innovation Framework Programme (CIP) continue } \\
\text { to facilitate venture capital investments and provide } \\
\text { guarantees for lending to SMEs" }\end{array}$ & $\mathrm{J} 4.1$ & $\begin{array}{l}\text { CIP facilitate venture capital } \\
\text { investments and provide } \\
\text { guarantees for lending to } \\
\text { SMEs }\end{array}$ \\
\hline $\mathrm{J} 5$ & $\begin{array}{l}\text { "With the financial support of the Commission, } \\
\text { a number of experts representing SMEs' interests } \\
\text { are helping to make European standards more SME- } \\
\text { friendly while the European standards organisations } \\
\text { are beginning to facilitate SMEs' access to standards, } \\
\text { e.g. by setting up SME helpdesks and portals" }\end{array}$ & $\mathrm{J} 5.1$ & $\begin{array}{l}\text { European standards more } \\
\text { SME-friendly }\end{array}$ \\
\hline J6 & $\begin{array}{l}\text { "In November 2010, the Commission opened an EU } \\
\text { SME Centre in China which provides information, } \\
\text { advice, training and matchmaking opportunities for } \\
\text { European SMEs willing to export to or invest in the } \\
\text { Asian market" }\end{array}$ & J6.1 & $\begin{array}{l}\text { Opportunities for European } \\
\text { SMEs willing to export to or } \\
\text { invest in the Asian market }\end{array}$ \\
\hline $\mathrm{J} 7$ & $\begin{array}{l}\text { "The ,Erasmus for Young Entrepreneurs' programme, } \\
\text { launched in 2009, offers on the-job training to nascent } \\
\text { and new entrepreneurs with a view to fostering cross- } \\
\text { border networking and business cooperation with } \\
\text { experienced entrepreneurs" }\end{array}$ & $\mathrm{J} 7.1$ & $\begin{array}{l}\text { Fostering cross-border } \\
\text { networking and business } \\
\text { cooperation }\end{array}$ \\
\hline $\mathrm{J} 8$ & $\begin{array}{l}\text { "Around } 250 \text { successful female entrepreneurs } \\
\text { now form the European Network of Female } \\
\text { Entrepreneurship Ambassadors set up by the } \\
\text { Commission in } 2009 \text { to inspire more women to } \\
\text { become entrepreneurs" }\end{array}$ & J 8.1 & $\begin{array}{l}\text { To inspire more women to } \\
\text { become entrepreneurs }\end{array}$ \\
\hline J9 & $\begin{array}{l}\text { "The Commission has put entrepreneurs and SMEs at } \\
\text { the heart of its innovation and research policy" }\end{array}$ & J9.1 & $\begin{array}{l}\text { SMEs the heart of } \\
\text { innovation and research } \\
\text { policy }\end{array}$ \\
\hline
\end{tabular}




\begin{tabular}{|c|c|c|c|}
\hline $\mathrm{J} 10$ & $\begin{array}{l}\text { "Cohesion Policy programmes and the European } \\
\text { Agricultural Fund for Rural Development (EAFRD) } \\
\text { are both key means of turning the priorities of the SBA } \\
\text { into practical action on the ground while ensuring } \\
\text { complementarity between EU, national and regional } \\
\text { support. Further investment should encourage } \\
\text { regions, to find specific niches in the innovation } \\
\text { landscape, based on 'smart specialisation strategies'" }\end{array}$ & $\mathrm{J} 10.1$ & $\begin{array}{l}\text { Smart specialisation } \\
\text { strategies }\end{array}$ \\
\hline $\mathrm{J} 11$ & $\begin{array}{l}\text { "All Member States have acknowledged the } \\
\text { importance of a rapid implementation of the SBA, } \\
\text { but the approach taken and the results achieved vary } \\
\text { considerably between Member States. While most } \\
\text { of them have adopted national targets for reducing } \\
\text { administrative burdens, not all Member States have } \\
\text { effectively reduced them" }\end{array}$ & J11.1 & $\begin{array}{l}\text { Results vary considerably } \\
\text { between Member States }\end{array}$ \\
\hline $\mathrm{J} 12$ & $\begin{array}{l}\text { "As a response to the financial and economic crisis, } \\
\text { most Member States have adopted measures to } \\
\text { enhance SMEs' access to finance, especially bank } \\
\text { lending, through advantageous subordinated loans, } \\
\text { loan guarantee schemes or microcredit programmes. } \\
\text { Six Member States (Belgium, Hungary, France, } \\
\text { Germany, Ireland and more recently Finland) have } \\
\text { created a "credit ombudsman". Given that access to } \\
\text { finance is in the end largely in the hands of Member } \\
\text { States, a stronger approach is warranted" }\end{array}$ & J12.1 & $\begin{array}{l}\text { Enhance SMEs' access to } \\
\text { finance/credit ombudsman }\end{array}$ \\
\hline $\mathrm{J} 13$ & $\begin{array}{l}\text { "Several governments support the internationalisation } \\
\text { of SMEs" }\end{array}$ & J13.1 & Internationalisation of SMEs \\
\hline $\mathrm{J} 14$ & $\begin{array}{l}\text { "No progress can be reported in the area of } \\
\text { simplification of bankruptcy procedures" }\end{array}$ & J14.1 & $\begin{array}{l}\text { No progress in } \\
\text { simplification of bankruptcy } \\
\text { procedures }\end{array}$ \\
\hline $\mathrm{J} 15$ & $\begin{array}{l}\text { "Finally, Member States are making good progress in } \\
\text { making it cheaper and faster to start up a company. } \\
\text { The average time and cost to start up a private limited } \\
\text { company in } 2010 \text { was } 7 \text { days (12 days in 2007) at a cost } \\
\text { of } € 399 \text { (€ } 485 \text { in 2007)" }\end{array}$ & J15.1 & $\begin{array}{l}\text { Good progress to start up } \\
\text { a company }\end{array}$ \\
\hline $\mathrm{J} 16$ & $\begin{array}{l}\text { "The implementation of the "Think Small First" } \\
\text { principle remains the core principle of the SBA. } \\
\text { It implies a simplification of the regulatory and } \\
\text { administrative environment in which SMEs are } \\
\text { operating, notably by designing rules according to it, } \\
\text { including the 'only once' principle or by using tools } \\
\text { like e-government and one-stop-shop solutions" }\end{array}$ & J16.1 & $\begin{array}{l}\text { Simplification of } \\
\text { the regulatory and } \\
\text { administrative environment } \\
\text { (of) SMEs }\end{array}$ \\
\hline
\end{tabular}


$\mathrm{J} 20$

"Improved and more efficient loan guarantee schemes are essential for SMEs which do not always have collateral. This is the case in particular for those borrowing small amounts, as improved provision of microcredit can boost entrepreneurship at national and regional levels. To this end the Commission has launched the Progress Microfinance Facility and is working on encouraging the exchange of good practices in microfinance, promoting training and offering support for microfinance institutions, notably in the framework of JASMINE, supporting the drafting of a code of good conduct. It is important that all banks, irrespective of their size, can have access to all EU financial instruments. Furthermore, banks could be encouraged to develop specific creditworthiness criteria for SMEs, taking into

J21 “The Single Euro Payments Area (SEPA) will allow SMEs to benefit from simpler payment arrangements with reduced costs and no need to use more than one bank account within the Single Market32. SEPA also provides a platform for the development of panEuropean e-invoicing and its mass adoption by SMEs"

J22 "The Commission will carry out an in depth analysis of the unfair commercial practices and contractual clauses in the business to business environment in the Single Market and table a legislative proposal if needed in order to protect businesses against unfair contractual terms"

J23 "SMEs are regularly harmed by anti-competitive practices, such as cartels or abuse of dominant position. To look at the options so that SMEs can effectively exercise their right to full compensation for such kind of damage, the Commission has launched a public consultation on a coherent European approach to collective redress"

J24 "Globalised markets offer new business opportunities to EU SMEs. According to a recent study, they are more internationally active than their counterparts in the USA and Japan: $25 \%$ of EU SMEs export or have exported at some point during the last 3 years, of which $13 \%$ exported outside the EU Single Market. At the same time, the study points to a huge untapped market potential, in particular in the BRIC countries37 which are estimated to account for about $60 \%$ of world GDP by 2030 . At present, these markets are only served by $7 \%$ to $10 \%$ of exporting EU SMEs" account, for example, qualitative criteria"

\begin{tabular}{|c|c|}
\hline $\mathrm{J} 20.1$ & $\begin{array}{l}\text { Improved and more } \\
\text { efficient loan guarantee for } \\
\text { SMEs }\end{array}$ \\
\hline $\mathrm{J} 20.2$ & $\begin{array}{l}\text { Progress Microfinance } \\
\text { Facility }\end{array}$ \\
\hline J21.1 & SEPA \\
\hline $\mathrm{J} 22.1$ & $\begin{array}{l}\text { Protect businesses against } \\
\text { unfair contractual terms }\end{array}$ \\
\hline J23.1 & $\begin{array}{l}\text { Public consultation on } \\
\text { a coherent European } \\
\text { approach to collective } \\
\text { redness }\end{array}$ \\
\hline J24.1 & $\begin{array}{l}\text { Globalised markets offer } \\
\text { new business opportunities } \\
\text { to EU SMEs }\end{array}$ \\
\hline
\end{tabular}

An empirical review of public policies on the sector of SMEs in the European Union 


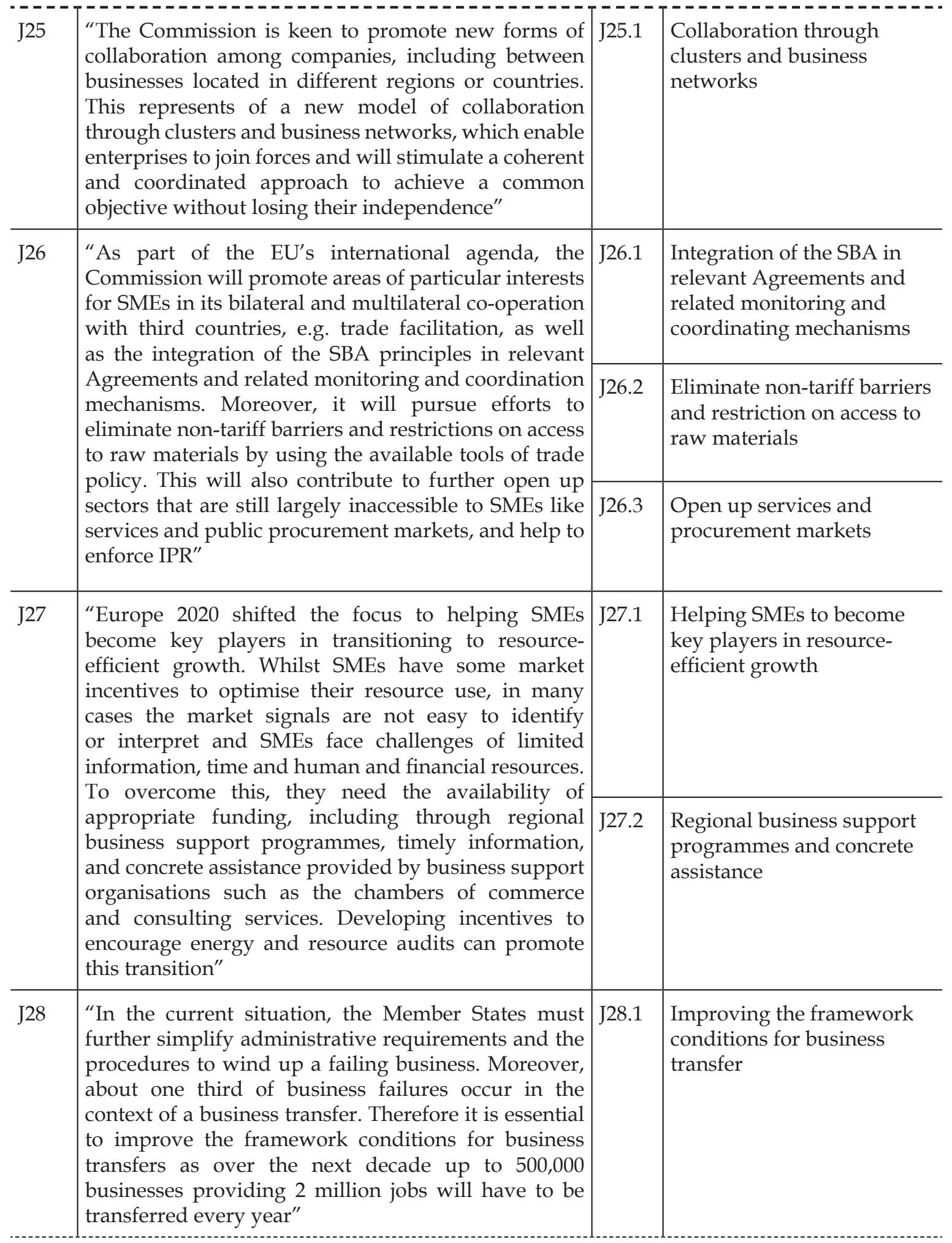




\begin{tabular}{|c|c|c|c|}
\hline $\mathrm{J} 29$ & $\begin{array}{l}\text { "As part of the Flagship initiative "An Agenda for New } \\
\text { skills and jobs", the Commission will assess future } \\
\text { skills needs in micro and craft (-type) enterprises. } \\
\text { Moreover, the "Youth on the Move" initiative puts the } \\
\text { accent on training to ensure that education systems } \\
\text { truly provide the right skills to start and manage an } \\
\text { SME" }\end{array}$ & J 29.1 & $\begin{array}{l}\text { Ensure that education } \\
\text { systems truly provide the } \\
\text { right skills to start and } \\
\text { manage an SME }\end{array}$ \\
\hline $\mathrm{J} 30$ & $\begin{array}{l}\text { "Too few innovative EU SMEs grow into large, } \\
\text { globally successful companies. The remaining barriers } \\
\text { for entrepreneurs to "bring ideas to market" must be } \\
\text { removed using a wide range of policy measures based } \\
\text { on a broad concept of innovation in products and } \\
\text { services which includes any change that speeds up } \\
\text { and improves the way businesses conceive, develop, } \\
\text { produce and market new products and services as set } \\
\text { out in the Innovation Union Communication" }\end{array}$ & J30.1 & $\begin{array}{l}\text { Broad concept of innovation } \\
\text { in products and services }\end{array}$ \\
\hline $\mathrm{J} 31$ & $\begin{array}{l}\text { "There are also SMEs which follow business models } \\
\text { different from the traditional capital-based companies. } \\
\text { This category, known as the "social economy", } \\
\text { includes non profit associations, foundations, co- } \\
\text { operatives, mutual societies and similar legal forms" }\end{array}$ & J31.1 & Social economy \\
\hline
\end{tabular}

